\title{
PRAWO DO WYNAGRODZENIA JAKO ZASADA ŻYCIA SPOŁECZNEGO
}

Praca, będąc obowiązkiem człowieka, stanowi jednocześnie źródło wielorakich uprawnień. Wszelkie uprawnienia należy rozpatrywać na tle ogółu praw właściwych człowiekowi, z których wiele zostało sformułowanych i ogłoszonych przez różne organizacje międzynarodowe, jak również poszczególne państwa. Poszanowanie praw człowieka jest podstawowym warunkiem pokoju na całym świecie i to zarówno w stosunkach wewnętrznych państw jak i w stosunkach międzynarodowych ${ }^{1}$. Z tych właśnie praw - jak zauważa Jan XXIII - ludzie czerpią światło najpierw dla regulowania swojego współżycia społecznego, potem dla ustalenia zasad miedzy obywatelami i władzami, dalej dla ułożenia stosunków między państwami, aż wreszcie dla wytyczenia zasad współżycia poszczególnych ludzi i państw, ze wszystkimi narodami, której zorganizowania domaga się dobro wspólne wszystkich ludzi na całej kuli ziemskiej².

* Ks. Jacek Szymański - kapłan diecezji włocławskiej, dr hab. teologii moralnej, rektor Wyższego Seminarium Duchownego we Włocławku, adiunkt na Wydziale Teologicznym UMK w Toruniu.

${ }^{1}$ Por. Jan Paweł II, Encyklika Laborem exercens, nr 16 (dalej LE).

2 Por. Jan XXIII, Encyklika Pacem in terris, nr 7. 
Prawa ludzkie wynikające $\mathrm{z}$ pracy tkwią zatem $\mathrm{w}$ podstawowych prawach osoby, ponieważ mają one specyficzny charakter. Praca jest powinnością wynikającą przede wszystkim z nakazu Stwórcy, jak również z faktu bycia człowiekiem. To właśnie człowieczeństwo i jego utrzymanie domaga się pracy. Człowiek powinien pracować mając na uwadze nie tylko swój własny rozwój, ale powinien pracować ze względu na swoją rodzinę, ze względu na społeczeństwo, którego jest częścią. Winien podjąć obowiązek pracy ze względu na naród, a także ze względu na całą rodzinę ludzką, ponieważ jest dziedzicem pracy pokoleń i współtwórcą przyszłości. Te właśnie zobowiązania stanowią szeroko pojętą moralną powinność pracy, do której należy się odwołać przy wyliczaniu i omawianiu uprawnień człowieka pracującego, będącego podmiotem pracy ${ }^{3}$.

\section{RELACJE POMIĘDZY PRACODAWCĄ A PRACOWNIKIEM}

Omawiając uprawnienie pracującego podmiotu do słusznej płacy należy przyjrzeć się stosunkom, jakie zachodzą pomiędzy pracodawcą bezpośrednim czy pośrednim a pracownikiem. Podział na pracodawcę bezpośredniego i pośredniego jest dość istotny, ze względu na kształtowanie się sprawiedliwych lub niesprawiedliwych stosunków w pracy i brania odpowiedzialności za nie. Kim zatem jest pracodawca pośredni? Pojęcie pracodawcy pośredniego obejmuje zarówno osoby, jak i różne instytucje, obejmuje także zbiorowe umowy o pracę ustalane przez powyższych, jak również cały ustrój społeczno-ekonomiczny i zasady z niego wynikające. Odpowiedzialność pracodawcy pośredniego różni się nieco od odpowiedzialności pracodawcy bezpośredniego, jest ona odpowiedzialnością merytoryczną, czyli pracodawca ten w sposób zasadniczy określa aspekty stosunku pracy i warunkuje postępowanie pracodawcy bezpośredniego. Pracodawca pośredni nie zwalnia z odpowiedzialności pracodawcę bezpośredniego, lecz określa jego postępowanie, wymagając respektowania praw człowieka pracującego ${ }^{4}$.

Pojęcie pracodawcy pośredniego można odnieść w szczególności do państwa, od którego wymaga się prowadzenia właściwej polityki pra-

${ }^{3}$ Por. LE, nr 16.

${ }^{4}$ Por. S. Fel, Podmioty pozarzadowe w "global governance", w: M. G. Woźniak (red.), Nierówności społeczne a wzrost gospodarczy. Problemy globalizacji i regionalizacji, Rzeszów 2006, s. 183-195. 
cy. W świecie zachodzą dziś różne powiązania między państwami, które opierają się na wymianie dóbr ekonomicznych, czyli eksporcie i imporcie. Między tymi powiązaniami powstają różnego rodzaju uzależnienia, które sprawiają, że żadne państwo nawet największe nie jest $\mathrm{w}$ pełni samowystarczalne. Mogłoby się wydawać, że te wzajemne zależności są normalne, ale w niektórych sytuacjach może dochodzić do różnych form niesprawiedliwości, dosięgających człowieka pracującego. Okazuje się, że zazwyczaj państwa wysoko uprzemysłowione wystawiają zbyt wysokie ceny za swoje produkty, a to może stać się w konsekwencji przyczyną rosnących dysproporcji między państwami. Te dysproporcje najczęściej dosięgają państw ubogich, a w konsekwencji mają wpływ na politykę pracy.

Natomiast pracodawca bezpośredni, którym jest konkretna osoba, czy instytucja, z którą pracownik zawiera bezpośrednio umowę o pracę, znajdując się w powyższej sytuacji gospodarczej, najczęściej będzie określał warunki pracy poniżej obiektywnych wymagań pracowników, chcąc czerpać jak największe zyski. W tych powiązaniach i zależnościach międzypaństwowych, najczęściej zostaje poszkodowany sam pracownik, dlatego też uprawnienia człowieka pracy nie mogą być jedynie pochodną systemów ekonomicznych, które kierują się wyłącznie zyskiem. Jedynie obiektywne uprawienia człowieka pracy winny stanowić podstawowe kryterium kształtowania ekonomii państwa i całego świata. W obronie uprawnień człowieka pracującego winny stanąć powołane do tego organizacje międzynarodowe, a także $\mathrm{w}$ poszczególnych państwach powołane do tego ministerstwa ${ }^{5}$. Ważne jest również poszukiwanie nowych rozwiązań, które ujęłyby procesy globalizacyjne $\mathrm{w}$ jakieś ramy. $\mathrm{W}$ świetle powyższego możemy zauważyć, że pracodawca pośredni ma znaczący wpływ na kształtowanie się całego społecznego ładu moralnego ${ }^{6}$.

W celu uściślenia powyższych zależności między rolą pracodawcy bezpośredniego i pośredniego odnieśmy się do obszaru rynku pracy i polityki społecznej. W społeczeństwach zazwyczaj możemy zaobserwować zatrudnienie zależne, a zatem regulacje dotyczące rynku pracy maja podstawowe znaczenie. Aby istniała zdrowa konkurencja na rynku pracy musi być i pracownik i pracodawca, którzy są równymi podmiotami, mogącymi w wolny sposób uzgadniać warunki pracy. W rzeczywistości wygląda to zupelnie inaczej. W przypadku wolnej konkurencji strony

\footnotetext{
${ }^{5}$ Por. LE, nr 16-17.

${ }^{6}$ Por. tamże.
} 
takiej umowy są równymi podmiotami jedynie formalnie. Faktem jest, że pracownicy znajdują się w gorszej sytuacji niż pracodawcy. Istnieją trzy zasadnicze powody takiej sytuacji ${ }^{7}$. Po pierwsze. Dochód z pracy stanowi dla pracownika podstawę egzystencji dla niego oraz dla jego rodziny i jest niejako przymuszony do warunków stawianych przez pracodawcę. Po drugie. Liczba miejsc pracy jest na ogół mniejsza niż chętnych, stanowi to zatem powód zakłócający działanie wolnej konkurencji i możliwe jest wywieranie nacisku przez dysponujących miejscami pracy. I po trzecie. Wolna konkurencja zakłócona jest przez tak zwane błędy rynku pracy znajdujące się po stronie podaży pracy.

Należy zauważyć, że możliwe są rozwiązania, które mają na celu zmniejszenie konsekwencji różnych niedoskonałości panujących na rynku pracy oraz wsparcia współpracowników. Wszelkie niedoskonałości panujące na rynku pracy starają się usunąć instytucje zajmujące się pośrednictwem pracy oraz takie działania, które wspierają doskonalenie umiejętności zawodowych, ich zmianę lub mobilność pracowników. Jednak należy zauważyć, że wszelkie działania na tym polu należą przede wszystkim do pracodawcy pośredniego ${ }^{8}$.

\section{PRAWO CZłOWIEKA DO ZATRUDNIENIA}

Aby można było mówić o uprawnieniach ludzi do słusznej płacy, należy najpierw posiadać samą pracę. Niezbywalnym prawem człowieka zdolnego do pracy jest zatrudnienie go, i to jeśli możliwe, zgodnie z jego umiejętnościami i przygotowaniem zawodowym. Wspomina o tym Vaticanum II, kiedy mówi, że „W podlegającym dziś zmianom w sprawach gospodarczych, jak i w nowych formach społeczeństwa przemysłowego, gdzie rozwija się automatyzacja, należy dbać, żeby każdy znalazł wystarczającą i odpowiednią dla siebie pracę oraz możliwość potrzebnego wyszkolenia technicznego i zawodowego" ${ }^{\prime \prime}$. Takie prawo do pracy zapewnia obywatelom polskim najważniejszy akt prawny, czyli Konstytucja, w której czytamy: „Każdemu zapewnia się wolność wyboru i wykonywania zawo-

7 Por. S. Fel, Dlaczego praca ludzka stanowi klucz do catej kwestii społecznej, w: J. Mazur (red.), Praca kluczem polityki społecznej, Lublin 2007, s. 121-137.

8 Por. tamże.

${ }^{9}$ Sobór Watykański II, Konstytucja duszpasterska o Kościele, nr 66. 
du oraz wyboru miejsca pracy"10. Natomiast w Kodeksie Pracy czytamy: „Każdy ma prawo do swobodnie wybranej pracy. Nikomu, z wyjątkiem przypadków kreślonych w ustawie, nie można zabronić wykonywania zawodu"11. Z powyższych dokumentów zarówno państwowych, jak i kościelnych wynika, że każdy człowiek objęty jest prawem do pracy. Coraz częściej to prawo dziś nie jest realizowane w wielu państwach, także w wysoko uprzemysłowionych.

Jeżeli człowiek jest już zatrudniony, to wtedy problemem kluczowym etyki pracy staje się sprawa sprawiedliwej zapłaty za wykonywaną pracę. Wydaje się bowiem, że nie ma ważniejszego sposobu na realizację sprawiedliwości między pracownikiem a pracodawcą jak sprawiedliwa zapłata. Nie jest ważne to, czy praca dokonuje się w ustroju prywatnej własności środków produkcji, czy w ustroju, gdzie własność uległa uspołecznieniu, ważne pozostaje bez wątpienia to, czy pracownik otrzymał odpowiednie wynagrodzenie za wykonana pracę ${ }^{12}$. Problemem kluczowym staje się zagadnienie sprawiedliwej zapłaty za wykonywana pracę ${ }^{13}$. Sprawiedliwość ustroju społeczno-ekonomicznego, a przede wszystkim jego właściwe funkcjonowanie może być oceniane wedle tego, czy praca ludzka jest prawidłowo wynagradzana ${ }^{14}$. Jan Paweł II formułuje to w sposób następujący: „W każdym ustroju, bez względu na panujące w nim podstawowe układy pomiędzy kapitałem a pracą, zapłata, czyli wynagrodzenie za pracę pozostaje konkretnym środkiem, dzięki któremu ogromna większość ludzi może korzystać z owych dóbr, które są przeznaczone dla powszechnego używania: są to zarówno dobra natury, jak też dobra będące owocem produkcji. Jedne i drugie stają się dostępne dla człowieka na podstawie zapłaty, jaką otrzymuje on jako wynagrodzenie za swoją pracę"15.

Katolicka myśl społeczna nie traktuje pracy wyłącznie jako dobra gospodarczego, jako towaru, który ma swoją cenę, czyli odpowiednią płacę $^{16}$. Zwraca na to uwagę Jan XXIII: „Pracy nie można traktować jako towar, gdyż jest ona bezpośrednim działaniem osoby ludzkiej"17.

\footnotetext{
${ }^{10}$ Konstytucja Rzeczpospolitej Polskiej, rozdz. II, art. 65, ust. 1.

${ }^{11}$ Kodeks Pracy, rozdz. II, art. 108. par. 1, w: Dz. U. 1998r., nr 21, poz. 94.

${ }^{12}$ Por. LE, nr 19.

${ }^{13}$ Por. A. Dylus, Kwestia płacowa dawniej i dziś, „Ethos” 8 (1995) nr 4, s. 99-112.

${ }^{14}$ Por. LE, nr 19.

${ }^{15}$ Tamże.

${ }^{16}$ Por. L. Dyczewski, Ptaca sprawiedliwa $i$ stuszna, „Ethos" 8 (1995) nr 4, s. 113-121.

${ }^{17}$ Jan XXIII, Encyklika Mater et magistra, nr 18.
} 
W związku z powyższym płacę należy wiązać z osobą pracownika, a dopiero na drugim miejscu z tym, co wyprodukowal ${ }^{18}$. Ustalenie słusznej płacy wymaga dostrzeżenia i uwzględnienia podmiotowego wymiaru pracy, gdyż pracownika wynagradza się za to czym on jest $\mathrm{w}$ procesie produkcji, nie zaś tylko za to, co wyprodukowat ${ }^{19}$.

Rozpatrując zagadnienie słusznej płacy, sięgnijmy do definicji płacy. Etymologicznie i historycznie płaca w językach romańskich (łac. salarium, franc. salaire), jest równoznaczna z zasiłkiem życiowym, żołdem. Jest to więc określona suma pieniędzy niezbędna by zakupić określone dobra, a także usługi gospodarcze niezbędne dla życia ludzkiego. W szerszym znaczeniu płaca jest naturalnym i powszechnym środkiem, dzięki któremu można sprostać obowiązkom wynikającym z odpowiedzialności pracownika, jako osoby ludzkiej. Płaca zatem przez ten fakt nie stanowi tylko problemu ekonomicznego, ale przede wszystkim problem społeczny. W ten właśnie sposób możemy dołożyć drugi człon do definicji pracy, a mianowicie, że jest ona udziałem pracowników najemnych $\mathrm{w}$ dochodzie społecznym. Płaca bowiem spełnia dwojaką funkcję: gospodarczo-wytwórczą oraz społeczno-gospodarczo-konsumpcyjną. Dopiero taka definicja pozwala na etyczną analizę problemu słusznej płacy ${ }^{20}$.

Warunkiem słusznej płacy - jak zauważył to już Leon XIII - jest wolność i słuszność umowy o pracę. Słuszna płaca musi zaspokoić słuszne potrzeby pracownika i jego rodziny, nie tylko w sensie statycznym, ale z uwzględnieniem poprawy jego standardu życiowego i umożliwienie mu awansu społecznego ${ }^{21}$. Także Pius XI, mówiąc o chrześcijańskim małżeństwie, postuluje, aby „wszyscy ojcowie rodzin, zależnie od stanu i miejsca zamieszkania mogli tyle zarobić, aby zapewnić sobie, żonie i dzieciom konieczne utrzymanie"22. Dalej papież zauważa, że zatrzymanie płacy lub jej uszczuplenie jest wielką niesprawiedliwością, zaliczaną przez Pismo Święte do najcięższych grzechów. Rzeczą niesprawiedliwą byłoby również wyznaczanie takiej płacy, która nie wystarcza na wyżywienie rodziny ${ }^{23}$. Ten sam papież zauważa, że jeżeli nie jest możliwe godziwe wynagrodzenie, to sprawiedliwość społeczna domaga

${ }^{18}$ Por. L. Dyczewski, dz. cyt., s. 117.

${ }^{19}$ Por. Jan Paweł II, Orędzie do wszystkich robotników Ameryki Środkowej, w: Dokumenty Nauki Społecznej Kościoła, cz. II, Rzym-Lublin 1987, s. 304.

${ }^{20}$ Por. Cz. Strzeszewski, Praca ludzka, Lublin 1978, s. 253.

${ }^{21}$ Por. Leon XIII, Encyklika Rerum novarum, nr 34-35.

${ }^{22}$ Pius XI, Encyklika Casti connubii, nr 117.

${ }^{23}$ Por. tamże. 
się reform, które pozwoliłyby pracownikowi na spełnienie powyższego warunku ${ }^{24}$.

Słusznym, czyli sprawiedliwym wymaganiem jest takie równoważenie płac, a także ich poszczególnych składników, aby można było stwierdzić, że pracownik uzyskał rzeczywisty i sprawiedliwy udział $\mathrm{w}$ bogactwie, twórczym wysiłku, który sam wnosi w działanie przedsiębiorstwa, życie zawodowe i gospodarkę narodową ${ }^{25}$.

Ojciec Święty Jan Paweł II porusza problem tak zwanej płacy rodzinnej w swojej "Ewangelii pracy”. Należy w tym miejscu wyjaśnić, że przez płacę rodzinną rozumie się jedno wynagrodzenie za pracę dane głowie rodziny. Jan Paweł II twierdzi, że byt rodzinny jest podstawowym wyznacznikiem ekonomii i polityki pracy. Zachowują one swoją właściwość etyczną tylko wtedy, gdy liczą się z potrzebami rodziny i jej prawami. Pracując więc, dorosły mężczyzna powinien zdobyć takie środki, by mógł utrzymać rodzinę. Natomiast macierzyństwo powinno być traktowane jako zadanie samo dla siebie, ponieważ to $\mathrm{z}$ nim wiąże się wielka praca matki, której nikt nie jest $\mathrm{w}$ stanie zastąpićéc.

Dla matki dom rodzinny i jego życie stanowić winny najważniejsze pole działania i troski. Jest dużym nadużyciem, jeśli matki, z powodu szczupłości zarobków ojca, muszą poza domem szukać pracy zarobkowej z zaniedbaniem swych właściwych prac i obowiązków, przede wszystkim wychowania dzieci ${ }^{27}$. Z kolei poszanowanie pracy winno łączyć się z wielkim szacunkiem dla macierzyństwa, ze względu na trud, jaki jest z nim związany. Dzieci potrzebują troski, miłości, uczucia, aby mogły się rozwijać jako osoby odpowiedzialne, dojrzałe moralnie i religijnie oraz psychicznie zrównoważone. Należy umożliwić kobiecie - matce, nie ograniczając przy tym jej wolności, ani też jej nie dyskryminując, oddanie się wychowaniu dzieci, odpowiednio do zróżnicowanych potrzeb ich wieku. Zaniedbanie tych obowiązków, które na pewno będzie spowodowane podjęciem przez matkę pracy, przyniesie szkodę zarówno społeczeństwu,

${ }^{24}$ Por. Pius XI, Encyklika Quadragesimo anno, rozdz. II, pkt. 4 (dalej QA).

${ }^{25}$ Por. Jan Paweł II, Przemówienie do robotników w Sao Paulo (3 VII 1980). Wspótpracownicy Boga w dziele stworzenia, ChŚ 95-96 (1980) nr 11-12, s. 217.

${ }^{26}$ Por. Jan Paweł II, Do pielgrzymów z Górnego Ślaska i Zagtębia Dąbrowskiego, Jasna Góra 6 VI 1979, w: Jan Pawet II. Nauczanie społeczne. Pielgrzymka do Polski 1979 r., t. I, Warszawa 1982, s. 137.

${ }^{27}$ Por. QA, rozdz. II, pkt. 4. 
jak i rodzinie, ponieważ uniemożliwi jej lub utrudni realizowanie pierwszorzędnych celów macierzyństwa ${ }^{28}$.

Cały system pracy należy tak zorganizować, aby poszanowane były wymogi osoby i wybranej przez nią formy życia, przede wszystkim życia domowego, z uwzględnieniem wieku i płci. Do codzienności należy fakt, że kobiety pracują niemal we wszystkich dziedzinach życia. Powinny one mieć jednak możliwości wykonywania w pełni swoich zadań z właściwa im naturą, oczywiście bez dyskryminacji zawodowej i nie pomniejszając przy tym szacunku dla ich aspiracji rodzinnych. Ważne jest również to, aby awans społeczny i zawodowy kobiet nie doprowadził do rezygnacji z tej podstawowej roli jaką jest bycie matką. W tej roli kobieta jest nie do zastąienia ${ }^{29}$.

„Ewangelia pracy" nie wprowadza żadnych przełomowych pojęć lecz jest kontynuatorką myśli o godziwej płacy rodzinnej. Należy przypomnieć, że w październiku 1961 roku w Turynie podpisano Europejską Kartę Społeczną Rady Europy, gdzie sformułowano prawo do godziwego wynagrodzenia, czyli takiego, które wystarcza dla przyzwoitego poziomu życia pracownika i jego rodziny ${ }^{30}$. Na uwagę zasługuje fakt, że taką koncepcję wysuną już $\mathrm{w}$ drugiej połowie XVIII wieku, Adam Smith, szkocki myśliciel i ekonomista, według którego istnieje pewna stopa, poniżej której nie można obniżyć na dłuższy czas zwykłego wynagrodzenia, nawet dla najniższej kategorii pracy ${ }^{31}$. Człowiek zawsze musi żyć ze swojej pracy, a jego płaca robocza musi co najmniej wystarczyć na utrzymanie. W niektórych jednak wypadkach musi ona być nieco wyższa, aby robotnik mógł założyć rodzinę. Najniższa kategoria zwykłych robotników powinna zawsze zarabiać dwa razy tyle, ile potrzebuje na własne utrzymanie, $w$ celu wychowania co najmniej dwojga dzieci ${ }^{32}$.

Należy dodać, że Zgromadzenie Ogólne ONZ w 1948 roku przyjęło Powszechna Deklaracje Praw Człowieka, w której stwierdza, że każdy pracujący ma prawo do odpowiedniego i zadawalającego wynagro-

${ }^{28}$ Por. Sobór Watykański II, Konstytucja dogmatyczna o Kościele, nr 52-69.

${ }^{29}$ Por. Jan Paweł II, Encyklika Laborem exercens, nr 19.

${ }^{30}$ Więcej na ten temat M. Kabaj, Encyklika "Laborem exercens" a polityka społeczna polskich rządów w czasie transformacji, w: J. Mazur (red.), dz. cyt. 2007, s. 139-168.

${ }^{31}$ Por. A. Smith, Badania nad natura $i$ przyczynami bogactwa narodów, Warszawa 1954 , s. $87-88$.

${ }^{32}$ Por. tamże. 
dzenia, które by zapewniło jemu i jego rodzinie taką egzystencję, jaka odpowiadałaby godności ludzkiej. W razie zaistniałej potrzeby wynagrodzenie takie mogłoby być uzupełniane innymi środkami pomocy społecznej33.

Powyższa Deklaracja nadała dużą rangę zasadzie godziwego wynagrodzenia, ale dopiero przyjęcie Europejskiej Karty Społecznej umożliwiło rozpowszechnienie na szeroką skalę realizację tej koncepcji w polityce społeczno-gospodarczej. W 1999 roku Polska ratyfikowała Europejską Kartę Społeczną, lecz nie ratyfikowała artykułu 4, który dotyczy właśnie kwestii płacowej. Wysokość wynagrodzeń w naszym kraju pokazuje, że nie są one realizacją zasady godziwej płacy rodzinnej.

Jeszcze większą niesprawiedliwością i grzechem „wołającym o pomstę do nieba" jest nadmierna rozpiętość wynagrodzeń. Rozpiętości krańcowe płac w Polsce należą do najwyższych w Europie. Przeciętne miesięczne wynagrodzenie brutto prezesów i członków zarządów pięćdziesięciu spółek giełdowych w 2005 roku wynosiło 196 tysięcy złotych. Natomiast pracownik uzyskujący przeciętne wynagrodzenie miesięczne w gospodarce narodowej wynoszące 2380 złotych, musiałby pracować na miesięczne wynagrodzenie prezesa aż 82 miesiące, czyli prawie 7 lat. Z powyższego wynika, że Polska jest krajem o wielkich kontrastach ekonomicznych i społecznych. Aby zmniejszyć tak duże rozpiętości płacowe należałoby przede wszystkim zwiększyć wynagrodzenia minimalne i niskie, po to, by mogły one spełniać wymogi wynagrodzeń godziwych, umożliwiających godne utrzymanie pracownika i jego rodziny ${ }^{34}$.

Konkludując powyższe refleksje dotyczące godziwego wynagrodzenia, należy stwierdzić, że to zagadnienie należy do fundamentalnych zasad życia społecznego. Bł. Jan Paweł II opiera tę kwestię na powszechnym prawie człowieka do korzystania z dóbr ziemi. Sprawiedliwa płaca stanowi bowiem sprawdzian danego ustroju politycznego. Przy określaniu zaś słusznej płacy należy mieć zawsze na względzie godziwe utrzymanie pracownika i jego rodziny, a także brać pod uwagę ich realne potrzeby, na które składają się wydatki związane z macierzyństwem, ubraniem, wykształceniem i wychowaniem dzieci, których współcześni pracodawcy nie uwzględniają.

${ }^{33}$ Por. Organizacja Narodów Zjednoczonych, Powszechna Deklaracja Praw Człowieka, art. 23, pkt. 3 .

${ }^{34}$ Por. M. Kabaj, Encyklika „Laborem exercens", s. 156. 


\section{THE RIGHT TO SALARY AS A PRINCIPAL OF SOCIAL LIFE}

\section{SUMMARY}

The subject of this article is an analysis of the right salary in the moral teaching reflection of John Paul II. The author shares his reflections based upon theological sources starting from the teaching of Vatican Council II until John Paul II. Rev. Szymański draws attention to the role of Church in honor of an individual employee and his family. 